Article

\title{
What Motivates Scientists in Emerging Economies to Become Entrepreneurs? Evidence from Vietnam
}

\author{
Thang Nguyen ${ }^{1, *}$, Lan Nguyen ${ }^{2}$, Scott Bryant ${ }^{3}$ and Hieu Nguyen ${ }^{4}$ \\ 1 Institute for Sustainable Development, National Economics University, Hanoi 100000, Vietnam \\ 2 Institute for Scientific Information, Vietnam Academy of Science and Technology, Hanoi 100000, Vietnam; \\ ntlan@isi.vast.vn \\ 3 Jake Jabs College of Business \& Entrepreneurship, Montana State University, Bozeman, MT 59717, USA; \\ bryant@montana.edu \\ 4 Faculty of Planning and Development National Economics University, Hanoi 100000, Vietnam; \\ nhhieu@neu.edu.vn \\ * Correspondence: nguyenvanthang@neu.edu.vn
}

Received: 21 January 2020; Accepted: 4 February 2020; Published: 7 February 2020

\begin{abstract}
Studies of scientist entrepreneurship have recognized a diverse range of proself motivations but have largely ignored the role of prosocial motivation. As technology inventions often bring in high positive externality, we argue that prosocial motivation is important for scientist entrepreneurship and sustainable development. Drawing from motivated information processing theory we develop a model linking proself and prosocial motivation with scientist entrepreneurship. The hypotheses were tested based on survey data from a sample of Vietnamese scientists. The results show that both proself and prosocial motivation are positively associated with scientist entrepreneurship. However, the positive association between prosocial motivation and scientist entrepreneurship is lessened by proself motivation. This study calls for more attention to prosocial motivation in theory and policy development on scientist entrepreneurship.
\end{abstract}

Keywords: scientist entrepreneurship; prosocial motivation; emerging economies; Vietnam

\section{Introduction}

Entrepreneurship has been recognized as an engine of sustainable development for both emerging and advanced economies [1-3]. Scientist entrepreneurship, which refers to the act of converting research inventions into new products or processes for commercial uses, promises a high potential contribution to development thanks to its innovative nature [4-11]. Scholars have recognized that motivations for scientist entrepreneurship are complex and multi-faceted [2], including financial rewards, reputation, and knowledge curiosity $[9,12]$. This diverse range of motivations, however, is mostly grounded in meeting self- or venture-related objectives [13] which are referred to as proself motivations. Prosocial motivations, which provide motivations to make social changes and/or to benefit others, have largely been ignored [3,14]. This is unfortunate since entrepreneurship in general, and scientist entrepreneurship in particular, are socially situated and aim to promote social development. Ignoring prosocial motivation essentially bypasses an important driver of scientist entrepreneurship. Studies in other settings, such as social entrepreneurship [13,14], fundraising [15], or security [16], have shown that prosocial and proself motivations are not mutually exclusive, and that prosocial motivations positively influence employees' creativity and performance. This suggests that prosocial motivation could play a role along with proself motivation in fostering scientist entrepreneurship.

In this study, we address the question of whether prosocial motivation is associated with scientist entrepreneurship, which is the likelihood a scientist will engage in the process of converting his or 
her inventions into new products or processes for commercial uses. This is an important extension of research in entrepreneurship motivations for several reasons. First, the core of scientist entrepreneurship worldwide is invention commercialization, which has a high level of positive externality [17-20]. Prosocial motivations encourage scientists to create value for a wider range of stakeholders and accept that only part of this value could be appropriated for themselves. Second, in both emerging and advanced economies, scientists' basic research depends on grants that have the explicit purpose of creating new knowledge for the entire society. This experience may create a sense of obligation to pay back society's investment in their success, which is an important part of prosocial motivation [21]. While prosocial motivation may make intuitive sense to scientists who work on solutions for societal problems, we are not aware of theoretically grounded studies that examine whether and how prosocial motivations influence scientist entrepreneurship. Third, systematic research on scientist entrepreneurship has been conducted mostly in advanced countries [3,5]. Scientist entrepreneurship in emerging economies faces unique challenges stemming from underdeveloped market institutions and sparse resources for research [3,5,22-24]. We are left with the puzzle of what motivates scientists to engage in entrepreneurial acts in the absence of market institutions that promote proself motivation.

To address these questions, we draw on motivated information processing theory $[16,25]$ to develop hypotheses on the roles of prosocial motivation on scientist entrepreneurship. The hypotheses were then tested on a sample of Vietnamese scientists who are working in public universities and research institutes. In the emerging economy of Vietnam, scientists are working under high institutional uncertainty, sparse resources, and yet with increasingly high requirements on both publications and commercialization [23,26-28]. The country's underdeveloped institutions may hinder scientists' value appropriation from their entrepreneurial acts [29,30], making prosocial motivations even more important for entrepreneurship.

We start with a brief literature review on scientist entrepreneurship and motivation and argue prosocial motivation has been largely ignored in current studies of scientist entrepreneurship. We then apply motivated information theory to develop hypotheses on main and interaction effects of prosocial motivation. Next, we present our research methodology and results. Finally, a discussion of theoretical and practical implications concludes our paper.

\section{Literature Review}

\subsection{Antecedents of Scientist Entrepreneurship}

Scholars have used several terminologies to describe the act of converting scientific research results into new products or new processes for commercial uses. These terminologies include scientist entrepreneurship [4,5], academic entrepreneurship [7,9,31-34], technology transfer [12] or commercialization [8,12,35-38], and industrial links activities. In this paper we define scientist entrepreneurship as the act of converting research results into new products/processes and introducing these into the market [4]. Scholars have identified common forms of scientist entrepreneurship, including starting new firms (either on their own or with help from their institutions), or joint-venturing with other business partners $[4,8,38]$. In addition, some scientists may shelve their inventions and/or informally commercialize the inventions (i.e., self-production with limited quantities) $[39,40]$. In this mode, the scientists convert their research results into new products, introduce them into the market, and accept a high risk of losing property rights.

Studies have confirmed a number of factors that influence scientist entrepreneurship $[4,7,8]$. First, access to financial resources is critical even prior to commercialization [8]. This is because the scientist often has to conduct many experiments to convert basic embryonic inventions into marketable products. Second, organizational factors contribute to scientist entrepreneurship. The presence of a Technology Transfer Office (TTO) and leadership support were found to be positively related to entrepreneurship [7,8,41-43]. The third set of factors relates to scientists' characteristics and/or their human capital. Male scientists are more likely to engage in entrepreneurship $[8,44,45]$, while age has an 
ambiguous relationship with entrepreneurship [7,44]. Seniority and academics' scientific productivity are found to be positively related to entrepreneurship [45]. From a life-cycle perspective, some studies have found that research achievement and career stages greatly influence scientists' motivation for commercialization $[6,39,46]$. Scientists at the mature stage and/or with excellent research achievements and reputations found it easier to commercialize their inventions.

Next, scientists' social networks positively related to their likelihood of engaging in entrepreneurial acts [41]. Previous research has shown that social networks influence the ability to discover business opportunities [7,32,47]. O'Gorman, et al. [48] found that social networks, especially networks with businesses, and experience in businesses related to the scientists' fields strongly influenced commercialization success.

Finally, scientists' motivation, including financial gain, recognition, and knowledge curiosity $[9,12,49]$ are found to positively relate to entrepreneurship. We will elaborate on this set of factors in the following sections. Table 1 summarizes that key factors that influence scientist entrepreneurship found in the literature.

Table 1. Key factors of scientist entrepreneurship in the literature.

\begin{tabular}{|c|c|c|}
\hline Factor & Key Variables and Propositions & Authors \\
\hline Organizational factors & $\begin{array}{l}\text { - } \quad \text { Leadership experience and support: positively related } \\
\text { to entrepreneurship } \\
\text { - } \quad \text { Presence of TTO: positively related to entrepreneurship }\end{array}$ & {$[7,8]$} \\
\hline Scientist human capital & $\begin{array}{l}\text { - Years holding PhD: Time since earning PhD degree } \\
\text { positively related to entrepreneurship } \\
\text { Entrepreneurship experience during PhD: Scientists } \\
\text { experience of entrepreneurship during PhD program } \\
\text { positively related to entrepreneurship } \\
\text { - Publications: Publications are positively related } \\
\text { to entrepreneurship }\end{array}$ & {$[4,39,46]$} \\
\hline Scientist social capital & $\begin{array}{l}\text { Social networks, especially with businesses, are positively } \\
\text { related to entrepreneurship }\end{array}$ & {$[4,5,7,32,41,47,48]$} \\
\hline Scientist motivation & $\begin{array}{l}\text { - Financial rewards, reputation, and knowledge motivation } \\
\text { are positively related to entrepreneurship }\end{array}$ & {$[9,12,49]$} \\
\hline
\end{tabular}

\subsection{Scientist Entrepreneurship Motivations}

Motivation has been defined as a set of psychological processes that directs, energizes, and sustains action $[14,50]$. Motivation to engage in entrepreneurial behaviors, e.g., to start new firms, has been widely studied [51-54]. Early studies proposed economic gain or profit maximization as the primary motivation for entrepreneurs [55-58]. Scholars then recognized more noneconomic factors such as autonomy, family security, work-life balance, or prestige [51-53] in motivating entrepreneurial action. Noneconomic motivations are especially important for social entrepreneurship, which has non-economic factors at its core.

In scientist entrepreneurship, motivation has been recognized as multi-faceted [9,12]. According to Lam [12], scientists can be motivated by a complex array of pecuniary and non-pecuniary factors in their commercial pursuits. Based on data from scientists working at five major U.K. research universities, Lam [12] demonstrated that scientists have a diverse range of motivations for entrepreneurship, including financial rewards, reputation, and knowledge curiosity. Similarly, in his qualitative study of scientist entrepreneurs from the Massachusetts Institute of Technology (MIT), he found a diverse range 
of motivations for spin-offs, including psychological and career-oriented motivations. Psychological motivations are a) the desire to put technology into practice; b) desire for wealth; and c) desire for independence. Career-related motivations include improving status within the university and becoming a "star scientist."

This diverse range of motivations for scientist entrepreneurship, nevertheless, is limited at present to proself motivations. In other words, these motivations are often grounded in meeting (or failing to meet) self- or venture-related objectives $[13,14]$. Motivations such as financial success, reputation, autonomy, or knowledge curiosity focus on fulfilling individual needs: their wealth, well-being, personal development, and satisfaction [59]. Prosocial motivation, referring to the motivation to make social changes and/or to benefit others, has largely been ignored in scientist entrepreneurship studies [14]. This is despite the fact that prosocial motivation has been studied in social entrepreneurship contexts, which purposefully gives priority to making social changes over seeking individual gains $[13,14]$.

Therefore, we observe two seemingly separate approaches to entrepreneurship motivations. People working on general entrepreneurial ventures, including scientist entrepreneurship, are portrayed as self-oriented and individually motivated [2]. Those working on social entrepreneurship, by contrast, are other-oriented and prosocially motivated. As De Dreu [60] argues, this portrait is misleading since scientists could be both proself- and prosocially motivated in their entrepreneurial acts. The difference may lie in the degree to which scientists are concerned with their own needs as well as the degree they are oriented toward the needs of others.

We argue that some level of prosocial motivation could be present in all scientist entrepreneurship, and that prosocial and proself motivation jointly influence scientist entrepreneurship. The presence of prosocial motivation is even more important for scientist entrepreneurship in developing countries where the institutions have not been developed to ensure the fulfilment of individual goals. The following sections elaborate on this argument.

\section{Hypothesis Development on Prosocial Motivation and Scientist Entrepreneurship}

\subsection{Relevance of Prosocial Motivation}

Prosocial motivation is a psychological state in which individuals are focused on the goal of benefiting other people based on a concern for the welfare of others $[13,14,60]$. It is the desire to expend effort based on a concern for helping or contributing to other people [61]. Several terms have been used to reflect essentially the same concept, including other-oriented motivation $[16,60]$ or motivation to make a prosocial difference [61]. Prosocial motivation can be trait related or situational. Several researchers conceptualized prosocial motivation as an individual value that broadly guides all behaviors [16,21]. Others studied it in specific situations or actions and did not assume that a person's prosocial motivation holds constant across different settings [14,62]. Scholars have concurred that prosocial and proself motivations are not mutually exclusive $[14,50,60,61]$. In other words, a person can have high levels of both prosocial and proself motivations when engaging in certain activities, such as venture creation.

We argue that prosocial motivation is relevant in studying scientist entrepreneurship for several reasons. First, scientist entrepreneurship or research commercialization has a high level of positive externality [17-20]. In other words, most scientist entrepreneurship aims at addressing societal development needs and only part of the resulting benefits could be appropriated by the scientists. While proself motivations relate to scientists' appropriation of the benefits, prosocial motivations promote scientist entrepreneurship for social development purposes, i.e., the positive externality and benefits of the actions. Second, the nature of basic research could nurture prosocial motivations which then encourage entrepreneurship. Scholars have found that prosocial motivation or value could be influenced by work experience [21]. Scientists' basic research depends largely on grants from governments or non-profit organizations. These grants are prosocial in nature with the explicit purpose of creating new knowledge for the entire society while also influencing the development 
of prosocial motivation in the scientists. Over time scientists may sense an obligation to pay back society's investment in their success [63], and converting their research into usable technology is a direct way for scientists to fulfill this obligation.

\subsection{Prosocial Motivations and Scientist Entrepreneurship}

We follow De Dreu, Nijstad, Bechtoldt and Baas [25] as well as Grant and Berry [16] by applying motivated information processing theory to explain the association between prosocial motivations and entrepreneurship. The essence of motivated information processing theory is that motivations shape cognitive processing: people selectively notice, encode, and retain information that is consistent with their desires $[16,25,50]$. Social motivations bias individual information processing by making people selective in encoding and retrieving information. People with high proself motivations are more likely to process information consistent with their self-interested orientation-using information to justify and guide actions that fulfill one's own needs. In contrast, those with high prosocial motivation are more likely to process information consistent with their prosocial perspective-using information to justify and guide actions in serving others [64].

Prosocial motivation influences scientist entrepreneurship through several mechanisms. First, prosocial motivation directs scientists to identify the usefulness, in addition to the novelty, of their ideas [16]. The usefulness of an idea depends on its applicability to address the problems or needs of a wide range of stakeholders or of the society at large. We argue that scientists with a strong prosocial motivation will be more likely to develop ideas that are ultimately useful to others. This is because prosocial motivation directs scientists' attention to the problems and needs of other people $[13,16,64]$. Prosocial motivation also encourages scientists to consider perspectives of others in their research and commercialization efforts. When an invention addresses the needs of a wide range of stakeholders, its chance of successful commercialization is enhanced.

Second, prosocial motivation facilitates integrative thinking [16]. According to the motivated information processing theory, prosocial motivation encourages scientists to include the perspectives of others, which makes them more likely to consolidate and align these perspectives in their thinking [25]. This integrative thinking encourages scientists to search for new information rather than just limit themselves to self-confirming information, to incorporate diverse information and different ideas, and to search for solutions that promise collective gains rather than singular interests [13]. Scientists' integrative thinking, therefore, would enhance the usefulness of their inventions.

Third, prosocial motivation directs the cost/benefit analysis of commercialization toward more collective, rather than singular, perspectives $[13,25,65]$. The logic of cost/benefit analysis suggests that a scientist would engage in an entrepreneurial act when the benefits outweigh the costs. Prosocial motivations induce scientists to view benefits more broadly and increase the weight placed on others' needs [13]. As discussed in the previous section, scientist entrepreneurship often involves positive externality. A higher weight placed on benefiting others would allow the cost/benefit calculation of entrepreneurial acts to include a wider range of benefits that may otherwise be ignored by purely proself motivated individuals. Besides, the focus on benefits to others would suppress the consideration of the considerable personal risks or costs in terms of time, resources, and emotional energy [13]. Therefore, we argue that prosocial motivation would bias the scientist's cost/benefit calculation more in favor of engaging in entrepreneurship.

In many settings a scientist with great technology and high prosocial motivation would have the option of selling the technology to a firm with similar social values and a large customer base. This option, however, is not yet feasible in Vietnam, where the underdevelopment of market institutions makes the transaction costs of technology transfer prohibitively high $[26,27]$ and where the concept of socially responsible businesses is at the nascent stage.

Therefore, we hypothesize:

Hypothesis 1. Scientists' prosocial motivation is positively related to entrepreneurship. 


\subsection{The Interaction between Proself and Prosocial Motivation}

Several scholars have proposed that prosocial and proself motivations may interact to influence creativity or performance $[14,16]$. In the context of entrepreneurship, the presence of these motivations may influence the recognition of business opportunities $[14,16]$. However, empirical investigations of such interaction effects are non-existent.

Prosocial motivation is found to work in parallel with proself motivation $[16,60]$. In other words, a scientist may engage in entrepreneurship because of both instrumental reasons (proself motivation) and genuine concern for others (prosocial motivation). According to the motivated information processing perspective, proself motivated individuals attend to self-relevant information and give greater consideration to information that reflects their self-beliefs and values [59,60]. A consequence of this consideration is a tendency to overlook social information that is inconsistent with their self-interests [59]. Individuals with high proself motivation are more likely to generate the personal potential consequences of various options and carefully evaluate these options based on their personal instrumental values. Scholars have found that instrumental values such as financial rewards, reputation, and curiosity positively influence scientist entrepreneurship [12,20].

As previously discussed, individuals with high prosocial motivation attend to social information (information related to and/or from others) and are more likely to evaluate business opportunities in light of benefits to others. They put a higher weight on others' needs and may even suppress the consideration of their personal costs in some circumstances [13]. When prosocial motivation is high, scientists will act less consistently with the predictions of models that are based on instrumental values $[59,60]$. This is because scientists with high prosocial motivation are less influenced by personal outcomes and considerations of self-interest. Instead, prosocially motivated scientists are driven more by social factors, such as procedural fairness and upholding psychological contracts with related stakeholders [25,65]. As stated in Hypothesis 1, we believe that prosocial motivation positively influences scientist entrepreneurship.

How about individuals who are high in both proself and prosocial motivations? These individuals are open to both self- and socially relevant information. Compared to those who are only high in proself motivation, they are open to more sources of information, including social beneficiaries. They are also less likely to reject social information that is inconsistent with their self-interests because they also consider the interests of others. Similarly, they are more sensitive to self-relevant information that signals business opportunities for personal gain than those who are only high in proself information. Consistent with the prediction by Grant and Berry [16], we argue that when both proself and prosocial motivations are high, scientists are open to a bigger pool of business opportunities and are more likely to recognize these opportunities than those who are high in only one type of motivation.

Therefore, we hypothesize:

Hypothesis 2. The positive association between prosocial motivations and scientist entrepreneurship is strengthened by proself motivation.

Figure 1 illustrates our theoretical model. 


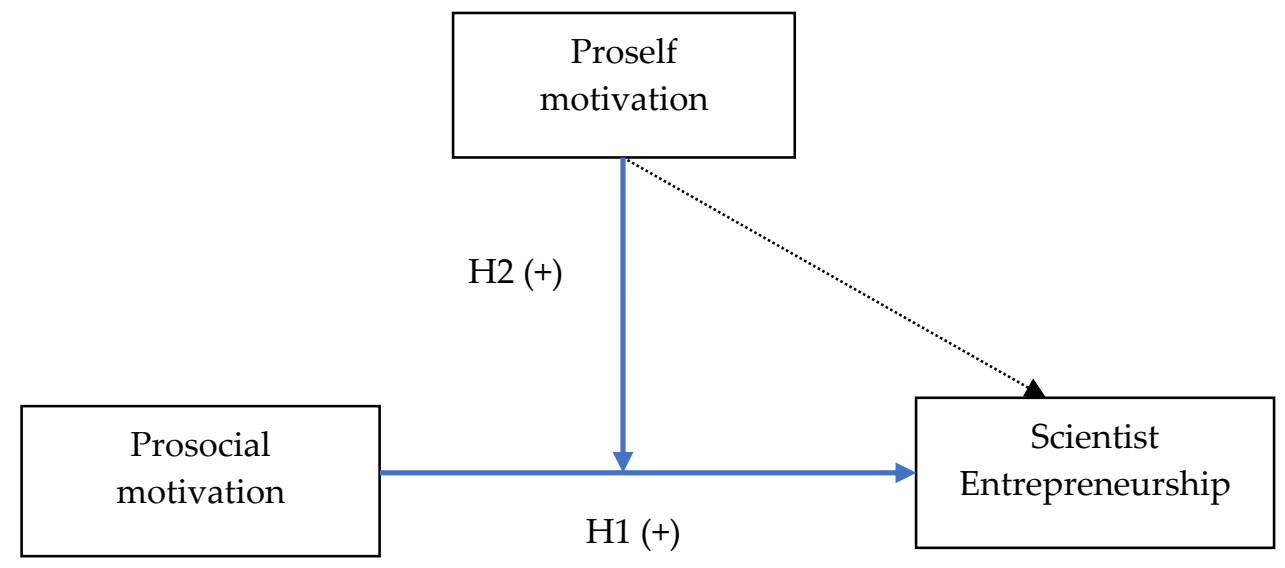

Figure 1. Theoretical Model.

\section{Methods}

\subsection{Research Context}

In Vietnam research activities were organized into three main domains: 1) research institutes of Vietnam Academy of Science and Technology (VAST) which were directly managed by the central government; 2) research institutes that belonged to various ministries; and 3) laboratories or research activities at universities [23]. The Ministry of Science and Technology oversaw the national research activities, while other ministries supervised their own institutes and universities.

While economic reform in Vietnam started in 1986, the reform in scientific research and technology development only started in the mid-1990s [23,26]. Two seemingly different reform measures have been promoted since then. First, research organizations have been encouraged to take more autonomy in their operations [23]. With a shortage of state budget funds, research organizations were asked to increasingly generate revenue from their own research. This created interest in scientist entrepreneurship that commercialized research. Second, the government has recently promoted more international research publications. The National Foundation for Science and Technology Development (NAFOSTED) was established in 2008 to fund quality basic research that results in internationally recognized publications. Research institutes and university teachers increasingly use international publications as a criterion for promotion to professor positions. Contrary to the desire for more commercialization, this action has created strong motivations for scientists to pursue international publications rather than commercialization. Research grants that result in international publications have become both reputationally and financially attractive. Many scientists would rather apply for new grants in order to create more publications than commercialize their past research.

Scholars and practitioners have documented several institutional challenges facing scientists in the commercialization of their research results. First, property rights are not always clear as to whom the results of state-funded research belong to and how to divide the benefits among the state, the institutions, and the individual scientists [26,27]. Second, information about the "supply and demand" for new inventions is fragmented and non-transparent. Third, businesses in Vietnam have not been very interested in cooperating with Vietnamese scientists, and even if they were, there is a lack of systems and bases for determining the "price" of inventions [26,27]. Finally, contract enforcement is weak in Vietnam, as it often is in other transition economies [66], further increasing the transaction costs associated with technology transfer.

\subsection{Sample and Procedure}

The purpose of the study was to examine whether prosocial motivation influences scientist entrepreneurship. We believe using a survey methodology was most appropriate in this case. Scholars have used surveys to collect data about scientist entrepreneurship at the individual level, since this 
method provides the most updated and detailed personal data available $[4,12,67,68]$. In addition, this method is most feasible in emerging economies, such as in Vietnam, since there is a lack of systematic data identifying scientists along with their entrepreneurial activities [5].

The sample consisted of scientists and professors in the fields of science and technology working at major public research institutes and universities in Vietnam. Researchers in social sciences were not included. In order to be included in the sample scientists needed to hold a PhD. Since there was a lack of systematic data identifying scientists along with their research and entrepreneurial activities, we had to compile the list from multiple sources. We approached major research institutes and universities to seek cooperation. Thirty-one major institutions provided lists with a total of 3204 scientists who met these criteria, but only 1759 people had correct telephones and/or emails. The scientists in the obtained list are working at 17 institutes under the Vietnam Academy of Science and Technology (VAST), the Vietnam Academy of Forest Science (under the Ministry of Agriculture \& Rural Development), and 14 public universities. To our knowledge, this is the first systematic and comprehensive survey of scientist entrepreneurship in Vietnam.

We first asked administrative staff at each institution to verify the contact information for the scientists. We then sent each scientist an email to solicit participation, the link to the online survey, and instructions on how to fill in the survey. Reminder emails were sent to non-respondents twice at an interval of one week. In total, 492 questionnaires were collected at the end of the survey, giving a response rate of $28 \%$. We compared the respondents with non-respondents on demographic variables (i.e., age, gender, qualification, and managerial positions) and found no difference. Response bias, if it exists, is negligible. The datasets generated during and/or analyzed during the current study are available from the corresponding author on reasonable request.

\subsection{Measures}

A summary of variables and measures is presented in Table 2.

Scientist entrepreneurship: This is a binary measure of whether the scientists engaged in entrepreneurial activities related to their research results or not. Entrepreneurial activities could be in any of the following modes: forming a new venture (either via start-up or joint venture with businesses), or self-production by the research team. Self-production is an informal mode in Vietnam where scientists organize the production by themselves without formally signing licensing/cooperation contracts with other partners or starting up new firms. The variable was coded 1 if the answer was "Yes" to any of these modes, and 0 if the answer was "No" to all modes.

Motivation: Two types of motivation were included, including proself motivations and prosocial motivation.

- We used Lam's (2011) measure of scientists' motivations in research activities to capture proself motivations (Table 2). Seven items were used for measuring reputation, knowledge curiosity, and financial rewards (Table 3).

- $\quad$ For pro-social motivation, we follow Renko [14] view that pro-social motivation is venture-specific rather than global to all activities. In the Renko [14] study, an entrepreneur was considered to have prosocial motivation if their first answer to one of the questions "Why do you want to start this new business?" or "What are the one or two main opportunities that prompted you to start this new business?" was categorized as "Help others; help community" or "Aid in economy; economic development; economy" (p. 10). Our qualitative interviews with twenty Vietnamese scientists revealed another motivation as "to repay society's investment in my personal development." Then based on the work of Renko [14] and our qualitative interviews we developed a three-item measure of prosocial motivation in scientist entrepreneurship (Table 3).

- $\quad$ For each type of motivation, respondents were asked to rate various items on their motivation to engage in entrepreneurial activities from 1 (not important) to 4 (important). A composite measure of each type of motivation was then generated by averaging the scores. 
Control variables: Following previous studies in scientist entrepreneurship [5], we controlled for the scientist's age, gender, field of study, and time since earning a Ph.D. Scientists' access to state research funding was controlled for by the number of projects and the average amount per project on which the scientists served as principal investigators during 2011-2016.

In addition, we also controlled for the presence of technology transfer units in the institutions. The presence of a unit that supports technology transfer was found to be positively related to entrepreneurship $[8,38,39,42]$. The surveyed scientists were from sixteen institutions under VAST, (Vietnam Academy of Forestry Science) and fourteen public universities. We checked whether these institutions had a unit that supported commercialization activities (i.e., licensing, start-up, connections with businesses, etc.). We coded 1 if they had a unit and 0 if they didn't.

Table 2. Summary of Measures.

\begin{tabular}{|c|c|c|}
\hline Variable & Measure & Note \\
\hline Prosocial motivation & $\begin{array}{l}\text { Scientist motivation to contribute to societal } \\
\text { development, help others, and repay society's } \\
\text { investment in their personal development }\end{array}$ & $\begin{array}{l}\text { We developed three items measuring } \\
\text { prosocial motivation, based on Renko's } \\
\text { (2012) article and our qualitative } \\
\text { interviews. The three items were on a } \\
\text { scale of } 1-4 \text {. }\end{array}$ \\
\hline Gender & Scientist gender & Dummy variable $($ Male $=1$, Female $=0)$ \\
\hline Field of study & $\begin{array}{l}\text { Six major fields of study were controlled for, } \\
\text { including Biology, Material Science, } \\
\text { Chemistry, Mechanics, Chemical engineering, } \\
\text { Physics }\end{array}$ & $\begin{array}{l}\text { A dummy variable was created for each } \\
\text { field, with a value of } 1 \text { if a scientist } \\
\text { belongs to the field, and } 0 \text { otherwise. }\end{array}$ \\
\hline Time since earning PhD & $\begin{array}{l}\text { Number of years since a scientist earned } \\
\text { his/her PhD }\end{array}$ & \\
\hline $\begin{array}{l}\text { Number of state-funded } \\
\text { grants }\end{array}$ & $\begin{array}{l}\text { Number of grants a scientist received from } \\
\text { the state during 2011-2016. }\end{array}$ & Continuous variable \\
\hline
\end{tabular}

\subsection{Analysis}

We ran Exploratory Factor Analysis (EFA) and reliability tests for the motivation measures. For hypothesis testing, standard probit models were run to test whether prosocial motivation (Model 1) and the interaction between prosocial and proself motivations (Model 2) were associated with entrepreneurship. In Model 2, to minimize the multicollinearity problem created by the interaction, we mean-centered proself and prosocial motivations. In all the models, standard errors are clustered at the organizational level.

\section{Results}

\subsection{Descriptive Statistics}

The surveyed scientists were on average 43.4 years old and $74 \%$ were male. The average length of time since earning their $\mathrm{PhD}$ was over 8.3 years. Fifty-five percent of surveyed scientists had a 
technology transfer support unit in their organizations, albeit the types and effectiveness of supports seemed to vary greatly. Finally, $34 \%$ of the surveyed scientists engaged in entrepreneurship activities during 2010-2016. The correlation matrix shows that scientist entrepreneurship significantly correlates with the motivation variables and scientists' fields of research. The motivation variables, on the other hand, significantly correlate with each other (Table 4).

We first ran factor analysis on all ten items of our motivation measures (seven items on proself and three items on prosocial motivations). Only two factors were extracted and accounted for 55\% of explained variance. The two factors were prosocial motivation (three items as designed) and proself motivation. Both measures have a Cronbach's alpha greater than 0.80, meeting standard requirement [69]. Table 3 presents factor loadings and Cronbach's alphas of motivation measures.

Table 3. Factor loading and Cronbach's alpha for motivation measures $\left.{ }^{*}\right)$.

\begin{tabular}{cc}
\hline & Factor Loadings \\
\hline & $\begin{array}{c}\text { Proself } \\
\text { Prosocial } \\
\text { Motivations }\end{array}$ \\
Reputions \\
To increase funding and other research resources & 0.675 \\
To build personal and professional networks & 0.645 \\
To provide work placement or job opportunities for students & 0.720 \\
Application and exploitation of research results & 0.706 \\
To create opportunities for knowledge exchange/transfer & 0.752 \\
To satisfy your intellectual curiosity & 0.626 \\
To increase your personal income & 0.595 \\
\hline Prosocial motivation (Cronbach's alpha: 0.816) & 0.851 \\
To contribute to country's development & 0.843 \\
To benefit and help others & 0.839 \\
\hline
\end{tabular}

$\left.{ }^{*}\right)$ The wording in the questionnaire reads as follows: "Please rate the importance of the following factors to you personally when engaging in research activities." 
Table 4. Correlation matrix $(\mathrm{N}=492)$.

\begin{tabular}{|c|c|c|c|c|c|c|c|c|c|c|c|c|c|c|c|c|}
\hline & Mean & SD & 1 & 2 & 3 & 4 & 5 & 6 & 7 & 8 & 9 & 10 & 11 & 12 & 13 & 14 \\
\hline 1. Age & 43.34 & 8.69 & & & & & & & & & & & & & & \\
\hline 2. Gender (Male) & 0.74 & 0.46 & 0.09 & & & & & & & & & & & & & \\
\hline 3. Year holding PHD & 8.29 & 7.27 & $0.79 * *$ & $0.15^{*}$ & & & & & & & & & & & & \\
\hline 4. Biology & 0.20 & 0.40 & 0.01 & $-0.17^{* *}$ & -0.04 & & & & & & & & & & & \\
\hline 5. Material Science & 0.12 & 0.32 & -0.04 & -0.01 & 0.02 & $-0.15^{* *}$ & & & & & & & & & & \\
\hline 6. Chemistry & 0.18 & 0.38 & 0.03 & -0.09 & 0.06 & $-0.22 * *$ & $-0.10^{*}$ & & & & & & & & & \\
\hline 7. Mechanics & 0.10 & 0.30 & 0.01 & $0.18^{* *}$ & 0.00 & -0.15 ** & -0.04 & $-0.14 * *$ & & & & & & & & \\
\hline 8. Chemical engineering & 0.04 & 0.20 & 0.06 & -0.01 & 0.07 & -0.08 & -0.05 & -0.02 & -0.04 & & & & & & & \\
\hline 9. Physics & 0.08 & 0.27 & 0.07 & $0.12^{*}$ & $0.15^{* *}$ & $-0.11 *$ & 0.06 & -0.07 & -0.05 & -0.02 & & & & & & \\
\hline 10. Tech Transfer unit & 0.48 & 0.65 & -0.05 & $0.20 * *$ & 0.01 & -0.04 & 0.05 & -0.01 & 0.01 & 0.06 & $-0.11 *$ & & & & & \\
\hline 11. No. of state-funded grants & 1.17 & 1.25 & $0.36^{* *}$ & $0.11 *$ & $0.44^{* *}$ & 0.03 & 0.06 & $0.15^{* *}$ & -0.03 & -0.08 & 0.08 & 0.08 & & & & \\
\hline 12. Average state-funded grant & 0.58 & 1.09 & $0.13^{* *}$ & 0.08 & $0.16^{* *}$ & $0.13^{* *}$ & -0.04 & 0.01 & -0.02 & -0.05 & -0.05 & $0.09 *$ & $0.31 * *$ & & & \\
\hline 13. Prosocial Motivation & 3.18 & 0.56 & 0.07 & -0.03 & 0.02 & -0.03 & -0.09 & 0.07 & 0.03 & -0.03 & -0.09 & 0.10 * & -0.02 & -0.03 & & \\
\hline 14. Proself Motivation & 3.13 & 0.48 & $-0.12 *$ & -0.06 & $-0.16^{* *}$ & 0.06 & $-0.14 * *$ & 0.01 & 0.02 & -0.02 & $-0.16^{* *}$ & $0.15^{* *}$ & -0.08 & 0.03 & $0.29 * *$ & \\
\hline 15. Entrepreneurship & 0.34 & 0.47 & 0.02 & 0.08 & 0.01 & -0.08 & $-0.10 *$ & 0.11 * & $0.11 *$ & $0.11 *$ & -0.08 & $0.18^{* *}$ & $0.11 *$ & 0.042 & $0.20 * *$ & $0.17^{* *}$ \\
\hline
\end{tabular}




\subsection{Hypothesis Testing}

To test our stated hypotheses, we ran probit models with scientist entrepreneurship as the dependent variable. Model 1 tested the main effects of motivation and the control variables (Hypothesis 1). Models 2 tested the interaction between proself and prosocial motivations on entrepreneurship. In Models 2, we only focused on the coefficient of the interaction term. Table 5 presents the marginal effects from the probit models.

Model 1 shows that prosocial motivation is positively and significantly related to the probability that scientists will engage in entrepreneurial actions $(0.342, p<0.05)$. Hypothesis 1 was strongly supported. Proself motivation was also positively and significantly related to scientist entrepreneurship $(0.427, p<0.001)$, consistent with findings by Lam [12]. This suggests that scientists in our sample engaged in entrepreneurship to enrich themselves and/or to benefit others, and these two purposes of entrepreneurship could co-exist.

Model 2 tested the moderating effect of prosocial motivation. In model 2, the interaction between prosocial motivation and proself motivation was significant and negative $(-0.278, p<0.01)$, suggesting that proself motivation lessens the positive association between prosocial motivation and entrepreneurship. This is opposite to Hypothesis 2, and we will suggest some possible explanations to this interesting finding in the discussion.

Table 5. Marginal effect on scientist commercialization (Probit Model, $\mathrm{N}=410$ ).

\begin{tabular}{|c|c|c|}
\hline & Model 1 & Model 2 \\
\hline \multicolumn{3}{|l|}{ CONTROL VARIABLES } \\
\hline \multirow[t]{2}{*}{ Age } & 0.00480 & 0.0008 \\
\hline & $(0.0160)$ & $(0.0055)$ \\
\hline \multirow[t]{2}{*}{ Gender (Male) } & 0.105 & 0.0326 \\
\hline & $(0.105)$ & $(0.0341)$ \\
\hline \multirow[t]{2}{*}{ Year holding PHD } & -0.00729 & -0.0029 \\
\hline & $(0.0144)$ & $(0.0050)$ \\
\hline \multirow[t]{2}{*}{ Biology } & -0.137 & -0.0372 \\
\hline & $(0.206)$ & $(0.0685)$ \\
\hline \multirow[t]{2}{*}{ Material Science } & $-0.293 *$ & -0.1030 \\
\hline & $(0.177)$ & $(0.0643)$ \\
\hline \multirow[t]{2}{*}{ Chemistry } & 0.162 & 0.0679 \\
\hline & $(0.148)$ & $(0.0529)$ \\
\hline \multirow{2}{*}{ Mechanics } & 0.290 & 0.127 * \\
\hline & $(0.223)$ & $(0.0714)$ \\
\hline \multirow[t]{2}{*}{ Chemical engineering } & $0.747^{* *}$ & $0.299 * * *$ \\
\hline & $(0.324)$ & $(0.1150)$ \\
\hline \multirow[t]{2}{*}{ Physics } & -0.262 & -0.0694 \\
\hline & $(0.220)$ & $(0.0771)$ \\
\hline \multirow[t]{2}{*}{ Tech. Transfer unit } & 0.235 & 0.0845 \\
\hline & $(0.191)$ & $(0.0635)$ \\
\hline \multirow[t]{2}{*}{ No. of state-funded grants } & 0.110 & $0.0406^{*}$ \\
\hline & $(0.0690)$ & $(0.0226)$ \\
\hline \multirow{2}{*}{ Average state-funded grant } & -0.0432 & -0.0107 \\
\hline & $(0.0734)$ & $(0.0247)$ \\
\hline \multicolumn{3}{|l|}{ MOTIVATIONS } \\
\hline \multirow{2}{*}{ Prosocial Motivation } & 0.342 ** & $0.158^{* * *}$ \\
\hline & $(0.172)$ & $(0.0526)$ \\
\hline \multirow{2}{*}{ Proself Motivation } & $0.427 * * *$ & $0.199 * * *$ \\
\hline & $(0.102)$ & $(0.0413)$ \\
\hline \multirow{2}{*}{\multicolumn{2}{|c|}{ Prosocial * Proself Motivations $(a)$}} & $-0.278^{* * *}$ \\
\hline & & $(0.0910)$ \\
\hline Pseudo R2 & 0.087 & 0.104 \\
\hline Wald chi-square & $169.33^{* * *}$ & $196.23^{* * *}$ \\
\hline
\end{tabular}

Standard errors (in parentheses) are clustered at organizational level. ${ }^{*} p<0.10,{ }^{* *} p<0.05,{ }^{* * *} p<0.01,(a)$ the interaction was created after the variables were mean-centered. 


\section{Discussion}

In this paper we addressed the question of whether prosocial motivation plays a role in promoting scientist entrepreneurship. We draw on motivated information processing theory to develop hypotheses on the direct and moderating effects of prosocial motivation on scientist entrepreneurship. Survey data from a sample of Vietnamese scientists showed that prosocial motivation positively relates to scientist entrepreneurship. However, the positive association between prosocial motivation and entrepreneurship is lessened when proself motivation increases.

Our study shows that prosocial motivation is important not only for social entrepreneurship $[13,14]$ but also for scientist entrepreneurship. We have demonstrated that with high positive externalities, scientist entrepreneurship is induced not only by scientists' motivations to fulfill their own needs but also by their motivations to benefit others. These proself and prosocial motivations work in parallel and are not mutually exclusive, as previous scholars have argued $[14,16,50,60]$. We have also found that prosocial motivation could interact with proself motivation to influence entrepreneurship, as scholars have suggested $[14,16]$.

We hypothesized that the presence of both proself and prosocial motivation create a synergy that enhances the creation and/or recognition of business opportunities, leading to a higher likelihood of scientists' engagement in entrepreneurship. The result was opposite to our hypothesis, i.e., proself motivation lessened the positive association between prosocial motivation and entrepreneurship. One possible explanation is in the process of opportunity evaluation. When both proself and prosocial motivations are high, the scientists may use a stricter set of evaluation criteria to select opportunities. This set of criteria requires the scientists to consider both individual gains and overall gains to society. For example, a highly profitable business opportunity still needs to meet some social requirements which would have been bypassed by those who are only high in proself motivation. By contrast, an opportunity with high social values still needs to meet certain personal cost/benefit thresholds that would have been ignored by purely prosocially motivated individuals. Thus, when both prosocial and proself motivations are high, a bigger pool of business opportunities may be recognized, but fewer opportunities would be selected than when only one type of motivation is high. Another possible explanation is context-related. Vietnam has been transitioning from a socialist to a market-oriented system. Under the socialist system, knowledge and innovation were treated as societal property $[63,70]$. Innovations should not create value for the innovators, and private gain was viewed as illegitimate. The primary motivation for scientists to transfer new technology to practice is for the development of the society at large, i.e., prosocial motivation. The current reform has recognized private wealth and interests of the scientists and started building the market institutions for commercialization [23,26,27]. As a result of the reform, proself motivation may emerge as a substitute for traditional prosocial motivation in driving scientists to entrepreneurial actions. This could contribute to our finding that, in the transition process, proself motivation lessened the positive association between prosocial motivation and entrepreneurship.

We are aware of some limitations in the study. As this is the first empirical study on scientist entrepreneurship in Vietnam, we lack data on the population of scientists to check for sample representativeness. As the data were collected from major research institutions and universities in Vietnam, we believe that our sample could include more successful scientists than the overall population. In addition, because we used a cross-sectional survey, we could not address the question of causality. While we argue that prosocial motivation induces scientist entrepreneurship, the causal direction could go the other way around. It is possible that by engaging in entrepreneurial acts, scientists gradually develop prosocial motivation, i.e., a desire to help others. Despite these limitations, the study offers important theoretical and managerial implications.

\subsection{Theoretical Implications}

The study extends the claim that entrepreneurship motivation is multi-faceted $[9,12,71]$ by including prosocial motivations. This is an important extension as previous studies outside of social 
entrepreneurship have largely focused on proself motivations $[2,14]$. The results demonstrate that scientists could engage in entrepreneurial activities both to fulfill their own needs and to benefit others. What may vary is the degree to which scientists are concerned with their own needs as well as the degree to which they are concerned about the needs of others. Future studies should examine whether prosocial motivation significantly influences entrepreneurship in any other settings. It is reasonable to suggest that prosocial motivation could be important for entrepreneurship that addresses issues with high positive externality, such as environmental protection, green consumption, or climate change. Another area for future research would be to explore whether proself or prosocial motivations matter to scientists' choices of the types of entrepreneurship they are engaging with as well as the performance of their entrepreneurial activities.

Our study also contributes to the literature of prosocial motivation. Previous studies have argued that proself intrinsic motivation strengthens the association between prosocial motivation and creativity or performance $[14,16,50]$. When extrinsic motivations (i.e., financial rewards and reputation) are considered, we found that proself motivation weakens the association between prosocial motivation and entrepreneurship. The fact that proself intrinsic and extrinsic motivations could moderate the associations between prosocial motivation with entrepreneurship in different ways deserves more examinations. Scholars have argued for a synergy between prosocial and intrinsic motivations in creation of useful and novel ideas [14,16]. Additionally, we argue for a trade-off between prosocial and extrinsic motivations in evaluation and appropriation of the ideas. Future research could probe further into these moderating effects.

Finally, the present study contributes to the literature of entrepreneurship in emerging economies by suggesting prosocial motivation as a potentially important factor in entrepreneurship. Scholars have agreed that emerging economies suffer from a lack of developed market institutions [30,72,73]. The lack of clear property right, effective contract enforcement, and transparent market information hinders entrepreneurs' efforts to appropriate value from their innovative ideas $[29,70]$. This institutional weakness could be off-set in part by entrepreneurs' prosocial motivation where the desire to help others and to facilitate society's development would make some individual losses acceptable. This suggests that prosocial motivation may be more important for entrepreneurship in emerging economies where market institutions are under-developed than in advanced economies. Future research could examine this issue by studying the role of prosocial motivation in various institutional settings.

\subsection{Policy Implications}

The notion of prosocial motivation is likely to be particularly important in such environments as contemporary Vietnam in which market institutions and infrastructure conducive to entrepreneurship has not been well developed. Despite three decades of reform, market institutions remain weak, especially in regulating such complex issues as intellectual property rights $[26,27,74]$. Scientist entrepreneurs found it hard to appropriate value from their entrepreneurial ventures. In this context, prosocial motivation could become an important driver of scientist entrepreneurship. This suggests that measures to promote prosocial values should not be ignored in the current institutional reform. Several measures such as encouraging scientists to socialize with beneficiaries and making information on how scientists' works contribute to others' lives could enhance scientists' prosocial motivation [61]. In other words, scientists' jobs should be designed to include more social aspects.

Entrepreneurship has been recognized as an important engine for development in emerging economies like Vietnam. Scientist entrepreneurship has a potential to contribute to this development by creating high value-added and innovative ventures. In the absence of effective market institutions that secure property rights, enforce contracts, and provide market information, scientist entrepreneurs face tremendous challenges in appropriating their commercialized inventions. In this context, prosocial motivation plays an important role in encouraging scientists to pursue entrepreneurship. While fulfilling one own's needs is a legitimate and important motivation, helping others is also a natural motivation for scientist entrepreneurship. 
Author Contributions: Conceptualization, T.N.; Data curation, L.N. and H.N.; funding acquisition, T.N.; investigation, L.N. and H.N.; methodology, T.N. and S.B.; project administration, L.N.; resources, H.N.; Supervision, T.N.; writing-original draft, T.N.; writing-review \& editing, S.B. All authors have read and agreed to the published version of the manuscript.

Funding: This research is funded by Vietnam National Foundation for Science and Technology Development (NAFOSTED) under grant number 502.02-2015.08.

Conflicts of Interest: The authors declare no conflict of interest.

\section{References}

1. Bruton, G.D.; Ahlstrom, D.; Si, S. Entrepreneurship, poverty, and Asia: Moving beyond subsistence entrepreneurship. Asia Pac. J. Manag. 2015, 32, 1-22. [CrossRef]

2. Mahto, R.V.; McDowell, W.C. Entrepreneurial motivation: A non-entrepreneur's journey to become an entrepreneur. Int. Entrep. Manag. J. 2018, 14, 513-526. [CrossRef]

3. Zeng, J. Fostering path of ecological sustainable entrepreneurship within big data network system. Int. Entrep. Manag. J. 2018, 14, 79-95. [CrossRef]

4. Aldridge, T.T.; Audretsch, D. The Bayh-Dole act and scientist entrepreneurship. Res. Policy 2011, 40, 1058-1067. [CrossRef]

5. Alshumaimri, A.; Aldridge, T.; Audretsch, D.B. Scientist entrepreneurship in Saudi Arabia. J. Technol. Transf. 2012, 37, 648-657. [CrossRef]

6. Audretsch, D.B.; Aldridge, T.T. Scientist commercialization as conduit of knowledge spillovers. Ann. Reg. Sci. 2009, 43, 897-905. [CrossRef]

7. Bercovitz, J.; Feldman, M. Academic entrepreneurs: Organizational change at the individual level. Organ. Sci. 2008, 19, 69-89. [CrossRef]

8. Markman, G.D.; Siegel, D.S.; Wright, M. Research and technology commercialization. J. Manag. Stud. 2008, 45, 1401-1423. [CrossRef]

9. Shane, S.A. Academic Entrepreneurship: University Spinoffs and Wealth Creation; Edward Elgar Publishing: Cheltenham, UK, 2004.

10. Thursby, J.G.; Thursby, M.C. Industry/university licensing: Characteristics, concerns and issues from the perspective of the buyer. J. Technol. Transf. 2003, 28, 207-213. [CrossRef]

11. Phan, P.H.; Foo, M.D. Technological entrepreneurship in emerging regions. J. Bus. Ventur. 2004, 19, 1-5. [CrossRef]

12. Lam, A. What motivates academic scientists to engage in research commercialization: 'Gold','ribbon'or 'puzzle'? Res. Policy 2011, 40, 1354-1368. [CrossRef]

13. Miller, T.L.; Grimes, M.G.; McMullen, J.S.; Vogus, T.J. Venturing for others with heart and head: How compassion encourages social entrepreneurship. Acad. Manag. Rev. 2012, 37, 616-640. [CrossRef]

14. Renko, M. Early challenges of nascent social entrepreneurs. Entrep. Theory Pract. 2012, 37, $1045-1069$. [CrossRef]

15. Grant, A.M.; Sumanth, J.J. Mission possible? The performance of prosocially motivated employees depends on manager trustworthiness. J. Appl. Psychol. 2009, 94, 927-944. [CrossRef]

16. Grant, A.M.; Berry, J.W. The necessity of others is the mother of invention: Intrinsic and prosocial motivations, perspective taking, and creativity. Acad. Manag. J. 2011, 54, 73-96. [CrossRef]

17. Antonelli, C.; Patrucco, P.P.; Quatraro, F. Productivity growth and pecuniary knowledge externalities: An empirical analysis of agglomeration economies in European regions. Econ. Geogr. 2011, 87, 23-50. [CrossRef]

18. Chu, P.-Y.; Lin, Y.-L.; Huang, C.-H.; Liu, T.-Y. Externality evaluation: An empirical study of ITRI. Int. J. Technol. Manag. 2009, 48, 280-294. [CrossRef]

19. De Cian, E.; Tavoni, M. Do Technol. externalities justify restrictions on emission permit trading? Resour. Energy Econ. 2012, 34, 624-646. [CrossRef]

20. Shane, S. Encouraging university entrepreneurship? The effect of the Bayh-Dole Act on university patenting in the United States. J. Bus. Ventur. 2004, 19, 127-151. [CrossRef]

21. Muethel, M.; Hoegl, M.; Parboteeah, K.P. National business ideology and employees' prosocial values. J. Int. Bus. Stud. 2011, 42, 183-201. [CrossRef] 
22. Shapira, P.; Wang, J. From lab to market? Strategies and issues in the commercialization of nanotechnology in China. Asian Bus. Manag. 2009, 8, 461-489. [CrossRef]

23. Tran, N.C. Turning science into business in developing countries: The case of vaccine production in Vietnam. J. Technol. Transf. 2007, 32, 425-434.

24. $\mathrm{Wu}, \mathrm{W}$. Managing and incentivizing research commercialization in Chinese Universities. J. Technol. Trans. 2010, 35, 203-224. [CrossRef]

25. De Dreu, C.K.; Nijstad, B.A.; Bechtoldt, M.N.; Baas, M. Group creativity and innovation: A motivated information processing perspective. Psychol. Aesthet. Creat. Arts 2011, 5, 81. [CrossRef]

26. Nguyen, Q.P. Thuc Trang Nghien Cuu Trien Khai va Thuong mai hoa cac ket qua Nghien Cuu/Sang tao cua cac nha khoa hoc/sang che tai Viet Nam va gioi y mot so Giai Phap co ban (Commercialization of Scientists' Research Results in Vietnam and Recommendations); Vietnam National University: Hanoi, Vietnam, 2015.

27. Nguyen, T.H. Commercialization of Research Results in the Business Sector of Vietnam (Thuc Trang Hoat Dong thuong Mai Hoa Sang che, Ket qua Nghien cuu cua khu vuc Doanh Nghiep tai Viet Nam); Bo Khoa hoc va Cong nghe (Ministry of Science and Technology): Hanoi, Vietnam, 2013.

28. Nguyen, T.V.; Rose, J. Building trust-Evidence from Vietnamese entrepreneurs. J. Bus. Ventur. 2009, 24, 165-182. [CrossRef]

29. North, D. Institutions, Institutional Change and Economic Performance; Cambridge University Press: Cambridge, MA, USA, 1990.

30. Smallbone, D.; Welter, F.; Ateljevic, J. Entrepreneurship in emerging market economies: Contemporary issues and perspectives. Int. Small Bus. J. 2014, 32, 113-116. [CrossRef]

31. Glassman, A.M.; Moore, R.W.; Rossy, G.L.; Neupert, K.; Napier, N.K.; Jones, D.E.; Harvey, M. Academic entrepreneurship: Views on balancing the Acropolis and the Agora. J. Manag. Inq. 2003, 12, 353-374. [CrossRef]

32. Haeussler, C.; Colyvas, J.A. Breaking the ivory tower: Academic entrepreneurship in the life sciences in UK and Germany. Res. Policy 2011, 40, 41-54. [CrossRef]

33. Teixeira, A.A.; Nogueira, J. Academic entrepreneurship in life sciences: The case of a moderate innovator country. J. Dev. Entrep. 2016, 21, 1650004. [CrossRef]

34. Zou, B.; Guo, J.; Guo, F.; Shi, Y.; Li, Y. Who am I? The influence of social identification on academic entrepreneurs' role conflict. Int. Entrep. Manag. J. 2019, 15, 363-384. [CrossRef]

35. Carayannis, E.G.; Cherepovitsyn, A.Y.; Ilinova, A.A. Technology commercialization in entrepreneurial universities: The US and Russian experience. J. Technol. Trans. 2016, 41, 1135-1147. [CrossRef]

36. Kang, J.; Gwon, S.-H.; Kim, S.; Cho, K. Determinants of successful Technol. commercialization: Implication for Korean Government-sponsored SMEs. Asian J. Technol. Innov. 2013, 21, 72-85. [CrossRef]

37. Miller, D.J.; Acs, Z.J. Technology commercialization on campus: Twentieth century frameworks and twenty-first century blind spots. Ann. Reg. Sci. 2013, 50, 407-423. [CrossRef]

38. Wright, M.; Birley, S.; Mosey, S. Entrepreneurship and university technology transfer. J. Technol. Trans. 2004, 29, 235-246. [CrossRef]

39. Dechenaux, E.; Thursby, J.; Thursby, M. Inventor moral hazard in university licensing: The role of contracts. Res. Policy 2011, 40, 94-104. [CrossRef]

40. Gianiodis, P.T.; Markman, G.D.; Panagopoulos, A. Entrepreneurial universities and overt opportunism. Small Bus. Econ. 2016, 47, 609-631. [CrossRef]

41. Grandi, A.; Grimaldi, R. Academics' organizational characteristics and the generation of successful business ideas. J. Bus. Ventur. 2005, 20, 821-845. [CrossRef]

42. Meysman, J.; De Cleyn, S.H.; Braet, J. Cash, community and coordination: The triple-C categorisation of technology transfer office organisational philosophy. Int. Entrep. Manag. J. 2019, 15, 815-835. [CrossRef]

43. Civera, A.; Donina, D.; Meoli, M.; Vismara, S. Fostering the creation of academic spinoffs: Does the international mobility of the academic leader matter? Int. Entrep. Manag. J. 2019, 1-27. [CrossRef]

44. Link, A.N.; Siegel, D.S.; Bozeman, B. An empirical analysis of the propensity of academics to engage in informal university Technology transfer. Ind. Corp. Chang. 2007, 16, 641-655. [CrossRef]

45. Perkmann, M.; Tartari, V.; McKelvey, M.; Autio, E.; Broström, A.; D’Este, P.; Fini, R.; Geuna, A.; Grimaldi, R.; Hughes, A.; et al. Academic engagement and commercialisation: A review of the literature on university-industry relations. Res. Policy 2013, 42, 423-442. [CrossRef] 
46. Levin, S.G.; Stephan, P.E. Research productivity over the life cycle: Evidence for academic scientists. Am. Econ. Rev. 1991, 81, 114-132.

47. Giuliani, E.; Morrison, A.; Pietrobelli, C.; Rabellotti, R. Who are the researchers that are collaborating with industry? An analysis of the wine sectors in Chile, South Africa and Italy. Res. Policy 2010, 39, 748-761. [CrossRef]

48. O'Gorman, C.; Byrne, O.; Pandya, D. How scientists commercialise new knowledge via entrepreneurship. J. Technol. Trans. 2008, 33, 23-43. [CrossRef]

49. Kolympiris, C.; Kalaitzandonakes, N.; Miller, D. Location choice of academic entrepreneurs: Evidence from the US biotechnology industry. J. Bus. Ventur. 2015, 30, 227-254. [CrossRef]

50. Grant, A.M. Does intrinsic motivation fuel the prosocial fire? Motivational synergy in predicting persistence, performance, and productivity. J. Appl. Psychol. 2008, 93, 48-58. [CrossRef]

51. Amit, R.; Zott, C. Value creation in e-business. Strateg. Manag. J. 2001, 22, 493-520. [CrossRef]

52. Kolvereid, L. Organizational employment versus self-employment: Reasons for career choice intentions. Entrep. Theory Pract. 1996, 20, 23-31. [CrossRef]

53. Shane, S.; Kolvereid, L.; Westhead, P. An exploratory examination of the reasons leading to new firm formation across country and gender. J. Bus. Ventur. 1991, 6, 431-446. [CrossRef]

54. Shaver, K.G.; Gartner, W.B.; Crosby, E.; Bakalarova, K.; Gatewood, E.J. Attributions about entrepreneurship: A framework and process for analyzing reasons for starting a business. Entrep. Theory Pract. 2001, 26, 5-28. [CrossRef]

55. Casson, M. The Entrepreneur: An Economic Theory; Rowman \& Littlefield: Lanham, MD, USA, 1982.

56. Kirzner, I.M. Discovery and the Capitalist Process; University of Chicago Press: Chicago, IL, USA, 1985.

57. Knight, F.H. Risk, Uncertainty and Profit; Hart, Schaffner and Marx: New York, NY, USA, 1921.

58. Schumpeter, J.A. Change and the Entrepreneur. In Essays of JA Schumpeter; Kessinger Publishing, LLC: Whitefish, MT, USA, 1934.

59. Meglino, B.M.; Korsgaard, A. Considering rational self-interest as a disposition: Organizational implications of other orientation. J. Appl. Psychol. 2004, 89, 946-959. [CrossRef] [PubMed]

60. De Dreu, C.K. Rational self-interest and other orientation in organizational behavior: A critical appraisal and extension of Meglino and Korsgaard (2004). J. Appl. Psychol. 2006, 91, 1245-1252. [CrossRef] [PubMed]

61. Grant, A.M. Relational job design and the motivation to make a prosocial difference. Acad. Manag. Rev. 2007, 32, 393-417. [CrossRef]

62. Bendell, B.L. I don't want to be green: Prosocial motivation effects on firm environmental innovation rejection decisions. J. Bus. Ethics 2017, 143, 277-288. [CrossRef]

63. Nguyen, T.V. Managing change in Vietnamese state-owned enterprises: What is the best strategy? Hum. Resour. Manag. Rev. 2003, 13, 423-438. [CrossRef]

64. De Dreu, C.K.; Beersma, B.; Stroebe, K.; Euwema, M.C. Motivated information processing, strategic choice, and the quality of negotiated agreement. J. Personal. Soc. Psychol. 2006, 90, 927-943. [CrossRef]

65. De Dreu, C.K.; Nijstad, B.A.; van Knippenberg, D. Motivated information processing in group judgment and decision making. Personal. Soc. Psychol. Rev. 2008, 12, 22-49. [CrossRef]

66. Welter, F.; Smallbone, D. Institutional perspectives on entrepreneurial behavior in challenging environments. J. Small Bus. Manag. 2011, 49, 107-125. [CrossRef]

67. Aldridge, T.T.; Audretsch, D.; Desai, S.; Nadella, V. Scientist entrepreneurship across scientific fields. J. Technol. Trans. 2014, 39, 819-835. [CrossRef]

68. Fini, R.; Grimaldi, R.; Sobrero, M. Factors fostering academics to start up new ventures: An assessment of Italian founders' incentives. J. Technol. Trans. 2009, 34, 380-402. [CrossRef]

69. DeVellis, R.F. Applied Social Research Methods Series, Vol. 26. Scale Development: Theory and Applications; Sage Publications, Inc.: Thousand Oaks, CA, USA, 1991.

70. Boisot, M.H. Institutionalizing the labour theory of value: Some obstacles to the reform of state-owned enterprises in China and Vietnam. Organ. Stud. 1996, 17, 909-928. [CrossRef]

71. Estay, C.; Durrieu, F.; Akhter, M. Entrepreneurship: From motivation to start-up. J. Int. Entrep. 2013, 11, 243-267. [CrossRef]

72. Puffer, S.M.; McCarthy, D.J.; Boisot, M. Entrepreneurship in Russia and China: The impact of formal institutional voids. Entrep. Theory Pract. 2010, 34, 441-467. [CrossRef] 
73. Smallbone, D.; Welter, F. Entrepreneurship and institutional change in transition economies: The Commonwealth of Independent States, Central and Eastern Europe and China compared. Entrep. Reg. Dev. 2012, 24, 215-233. [CrossRef]

74. Nguyen, Q.A.; Sullivan Mort, G.; D'Souza, C. Vietnam in transition: SMEs and the necessitating environment for entrepreneurship development. Entrep. Reg. Dev. 2015, 27, 154-180. [CrossRef]

(C) 2020 by the authors. Licensee MDPI, Basel, Switzerland. This article is an open access article distributed under the terms and conditions of the Creative Commons Attribution (CC BY) license (http://creativecommons.org/licenses/by/4.0/). 